Logos Universality Mentality Education Novelty: Economics and Administrative Sciences

ISSN: 2284-5984 | e-ISSN: 2501-0425

Covered in: ERIH+; CEEOL; Index Copernicus; CrossRef; CrossCheck; J-Gate; Google Scholar; Ideas RePeC;

Econpapers; Socionet; KVK; WorldCat, EBSCO.

2021, Volume 6, Issue 1, pages: 57-68| https://doi.org/10.18662/lumeneas/6.1/29

\section{Strategic Guidelines on Employment}

\author{
Alunica MORARIU ${ }^{1}$ \\ ${ }^{1}$ Associate Professor PhD, "Stefan cel \\ Mare" University of Suceava, Romania, \\ alunica.morariu@gmail.com
}

\begin{abstract}
Through this paper, the author aims to highlight the most important aspects of the new strategic guidelines on employment, while presenting and discussing some quantitative and qualitative aspects from this context. Thus, after addressing the concerns at the level of the European Union regarding the efficiency of the employment policies, the author stops on the strategic orientations of Romania regarding the employment. Particular emphasis is placed on the issue of difficulties, risks and weaknesses, to a lesser extent in other EU countries, followed by presenting the response measures of government factors and the strategic guidelines adopted, as well as the expected results.
\end{abstract}

Keywords: employment; European Union; strategies; CoE orientations; measures; results.

How to cite: Morariu, A. (2021). Strategic Guidelines on Employment. Logos Universality Mentality Education Novelty: Economics and Administrative Sciences, 6(1), 57-58. https://doi.org/10.18662/lumeneas/6.1/29 


\section{European Union - encouraging, supporting and evaluating Member States' efforts in employment policies}

About ten years before Romania's accession to the European Union, there was the problem of setting several objectives aimed at increasing the number of jobs within the Member States, but also the quality of their conditions, in the context of free movement of persons and the manifestation of migration (Bostan \& Grosu, 2010; Burciu, 2008; Morariu, 2014). These objectives (including: the development of a highly qualified human resource, the prolongation of the active life of the elderly, the increase of youth employment, the improvement of the employment structure and the participation of vulnerable women/people in the labor market), found in numerous strategic documents, have been achieved in different proportions (compared to those set out in the Europe 2020 Strategy), the overall trend being satisfactory.

We recall that in connection with employment, the Europe 2020 Strategy (when the target set for 2020 was to ensure an employment rate of $75 \%$ for people aged between 20 and 64) mentioned that "due to demographic changes, our workforce is declining. Only two-thirds of our workforce currently has a job, compared to over $70 \%$ in the US and Japan. The employment rate is low, especially among women and older workers. Young people were severely affected by the crisis, experiencing an unemployment rate of over $21 \%$. There is a high risk that people who are not integrated into the labor force or who have poor connections with it will lose ground in the labor market." (European Commission, 2010).

It is important that, prior to the pandemic crisis, "Employment continues to grow, albeit at a slower pace than in previous years. In the third quarter of 2019, 241.5 million people had a job in the EU, the highest level ever. Older and highly skilled workers continue to be the main drivers of employment growth. Due to the slowdown in economic increase, growth is also expected to slow down in the last quarter of 2019 and 2020. Therefore, the employment rate of people aged 20-64 is currently expected to increase in 2020 , it will be close to the $75 \%$ target of the Europe 2020 Strategy, but will remain slightly below that target"(European Commission, 2019).

We illustrate below a social scoreboard, which highlights the positive trends in the European Union labor market and in the social field (before the pandemic crisis period), but also the challenges that still remain. (Figure 1). 
The net earnings of an unmarried worker with a medium salary

The impact of social transfers on poverty reduction

Individual level of digital skills

Children under 3 years of age in formal care

Gender disparity in employment

People who leave the education and training systems early

The rate of risk of poverty or social exclusion

The Youth NEET rate

The ratio beteen the upper and lower quintile

Unsatisfied self-reported medical care needs

Employment rate

Unemployment rate

Per capita GDHI growth

Long-term unemployment rate

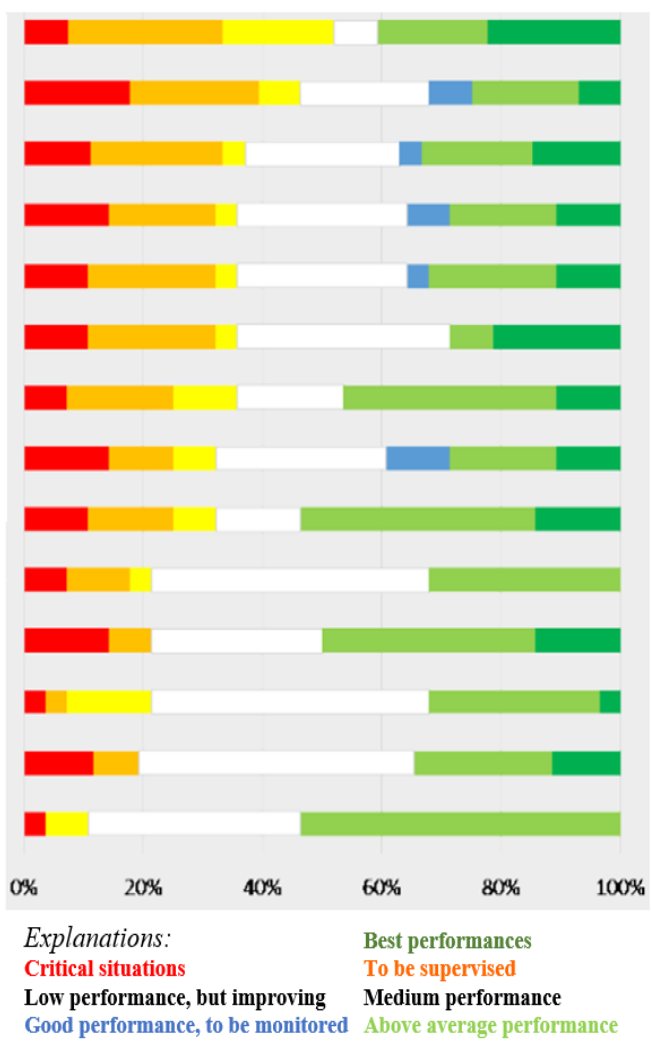

Figure 1. Social scoreboard - trends in the European Union labor market

Source: European Commission (2019)

It should be noted that each Member State is primarily responsible for employment policy, but the European Commission is "working with them to pursue a coordinated strategy: the European Employment Strategy." (EESC, 2020). At the same time, the European Union "encourages cooperation between Member States and supports and evaluates the efforts made, in particular through the European Semester, of the employment guidelines and the monitoring of national policies" (EESC, 2020).

All this explains the regular drafting of the Joint Employment Report, the National Reform Programs and the recommendations that take into account the specificities of each state. 


\section{Strategic European guidelines for achieving high employment standards}

At European Union level, guidelines are laid down annually for the employment policies of the Member States (Table no. 1), to be taken into account by Member States (requiring reporting under Article 148 (3) from TFEU), in their employment policies and within the reform programs.

Table 1. European Union guidelines for the employment policies of the Member States for 2020 and their directions

\begin{tabular}{|c|c|c|}
\hline No. & Guidelines for 2020 & Concentration directions for EU Member States \\
\hline 1 & $\begin{array}{l}\text { Stimulating labor } \\
\text { demand }\end{array}$ & $\begin{array}{l}\text { - actively promoting a sustainable market economy, facilitating and supporting } \\
\text { investments in creating quality jobs; } \\
\text { - shifting work taxes to other resources that are more supportive of employment and } \\
\text { growth, and are in line with climate and environmental goals; } \\
\text { - ensuring adequate and fair wages for workers, benefiting from collective } \\
\text { agreements or adequate statutory minimum wages. }\end{array}$ \\
\hline 2 & $\begin{array}{l}\text { Strengthening the work } \\
\text { supply and improving } \\
\text { access to jobs, skills } \\
\text { and competences }\end{array}$ & $\begin{array}{l}\text { - to promote sustainability, productivity, employability and human capital, } \\
\text { promoting relevant knowledge, skills and competences throughout people's lives, } \\
\text { responding to current and future labor market needs; } \\
\text { - to promote equal opportunities for all by addressing inequalities in education and } \\
\text { training systems; } \\
\text { - to provide unemployed and inactive people with effective, timely coordinated and } \\
\text { personalized assistance; } \\
\text { - to support a work environment adapted for people with disabilities; } \\
\text { - to address the disparities in terms of employment and remuneration. }\end{array}$ \\
\hline 3 & $\begin{array}{l}\text { Strengthening the } \\
\text { functioning of labor } \\
\text { markets and the } \\
\text { effectiveness of social } \\
\text { dialogue }\end{array}$ & $\begin{array}{l}\text { - to collaborate with the social partners for fair, transparent and predictable working } \\
\text { conditions, ensuring a balance between rights and obligations; } \\
\text { - to activate and effectively empower those who can participate in the labor market; } \\
\text { - to provide adequate unemployment benefits for a reasonable period of time, in } \\
\text { accordance with their contributions and national eligibility rules; } \\
\text { - to adequately support the mobility of students and workers, in order to improve } \\
\text { their skills and employability, to exploit the full potential of the European labor } \\
\text { market; } \\
\text { - to ensure the real and timely involvement of the social partners in the design and } \\
\text { implementation of reforms and policies for social and, where appropriate, economic } \\
\text { employment. }\end{array}$ \\
\hline 4 & $\begin{array}{l}\text { Promoting equal } \\
\text { opportunities for all, } \\
\text { social inclusion and } \\
\text { combating poverty }\end{array}$ & $\begin{array}{l}\text { - to promote inclusive labor markets open to all, by implementing effective measures } \\
\text { to combat all forms of discrimination and to promote equal opportunities for all; } \\
\text { - to ensure equal treatment for the underrepresented groups in terms of employment, } \\
\text { social protection, long-term health and care services, education and access to goods } \\
\text { and services; } \\
\text { - to modernize social protection systems; } \\
\text { - to develop and integrate the three components of active inclusion: adequate income } \\
\text { support, inclusive labor markets and access to services that enable quality and } \\
\text { individual needs to be met; } \\
\text { - to ensure that everyone, including children, has access to essential services; } \\
\text { - to ensure the sustainability and adequacy of the pension systems for employees, } \\
\text { and for those who are self- employed. }\end{array}$ \\
\hline
\end{tabular}

Source: European Union (2020) 
The content of Council Decision 2020/1512 from 13 October 2020 on guidelines for the employment policies of the Member States shows the importance that the European Union attaches to the need for "the availability of quality and accessible services, including in terms of prices, such as education and early care, extracurricular care, education, training, housing, healthcare and long-term care, which are essential conditions for ensuring equal opportunities. Particular attention should be paid to combating poverty and social exclusion, including in-work poverty and child poverty, including in relation to the impact of the COVID-19 pandemic crisis" (European Union, 2020).

Recently, in the field of employment, skills and social protection, three main EU targets have been set, with a deadline of 2030: "(i) at least $78 \%$ of the population aged 20 to 64 should be employed by 2030 , (ii) at least $60 \%$ of all adults should attend training each year, (iii) the number of people at risk of poverty or social exclusion should be reduced by at least 15 million" (European Parliament, 2021). To a large extent, the alarm signal is given by the fact that we find a still high share $(12.6 \%$ in 2019$)$ of people aged between 15 and 29 who do not attend courses of any kind, establishing - the reduction of the respective share by 3.6\%, until the year 2030 .

Therefore, the role of increasing the supply of formal education and care for preschool children or reducing the gender gap in employment must be of particular importance.

\section{Romania's employment strategy options}

At present, the national labor market is characterized by a number of difficulties, risks and weaknesses, to a lesser extent in other countries. (Anghelache et al., 2016). Government documents prepared in the context of the proposal for the National Employment Strategy 2021-2027 refer to those found in the quadrant below (Table 2). 
Table 2. Main weaknesses and risks of the national labor market (Selection from National Labor Market 2021-2027

\begin{tabular}{|c|c|}
\hline$W e$ & Risks \\
\hline $\begin{array}{l}\text { - Negative demographic evolutions; } \\
\text { - Decreasing the available labor force due to migration and } \\
\text { external mobility; } \\
\text { - Large number of inactive people (especially from } \\
\text { vulnerable groups)who can hardly be included in the labor } \\
\text { market; } \\
\text { - Low degree of internal labor mobility; } \\
\text { - Low participation of the unemployed but also of the labor } \\
\text { force in general in programs to increase the level of skills; } \\
\text { - Difficult integration of young people from disadvantaged } \\
\text { categories; } \\
\text { - High level of school dropout; } \\
\text { - Low labor productivity; } \\
\text { - Mechanisms for anticipating the need for skills and for } \\
\text { monitoring and evaluating active policies that require } \\
\text { development and correlation; } \\
\text { - Monitoring and mainly administrative evaluation of the } \\
\text { impact of the active measures; } \\
\text { - Development and reduce access to vocational training in } \\
\text { companies/poor investment in continuous training of } \\
\text { their own employees, in the context of the need for } \\
\text { restructuring, modernization, absorption of research } \\
\text { results; } \\
\text { - insufficient correlation of the educational system with the } \\
\text { labor market requirements; } \\
\text { - Low number of vocational training courses for students } \\
\text { during their studies; } \\
\text { - High level of in-work poverty compared to other EU } \\
\text { Member States; } \\
\text { - Underdeveloped physical infrastructure; } \\
\text { - Low level of digital literacy among the population(...). }\end{array}$ & $\begin{array}{l}\text { - Continuing and emphasizing the migration and } \\
\text { external mobility of labor force; } \\
\text { - Negative demographic perspectives; } \\
\text { - Slow pace of new job creation; } \\
\text { - Slow professional reconversion of laid off } \\
\text { workforce } \\
\text { - Insufficient use of the results of analyzes and } \\
\text { studies to substantiate policies; } \\
\text { - Underfunding of active measures and other } \\
\text { interventions developed for the labor market; } \\
\text { - Inadequate access and lack of basic skills among } \\
\text { vulnerable people,which will lead to their reduce } \\
\text { participation in the labor market; } \\
\text { - Reduced ability to anticipate the skill needs of new } \\
\text { jobs within circular economy; } \\
\text { - Undeclared but well-paid work which may lead } \\
\text { employees to accept such practices; } \\
\text { - The sharp rise in the minimum wage that could } \\
\text { cause some industries to become uncompetitive; } \\
\text { - Increasing the pay gap with another countries; } \\
\text { - Labor market segmentation; } \\
\text { - Increasing in-work poverty; } \\
\text { - Maintaining unemployment benefits at current } \\
\text { levels amid a slowdown in growth can substantially } \\
\text { affect the incomes of the unemployed people; } \\
\text { - High level of poverty and social exclusion that will } \\
\text { be accentuated by the crisis generated by the } \\
\text { - High decline in economic activities in certain } \\
\text { - Hid } \\
\text { economic sectors and their vulnerability in the post- } \\
\text { pandemic period. }\end{array}$ \\
\hline
\end{tabular}

Source: Romanian Government (2021a)

Between 2014 and 2020, Romania made multiple efforts in order to reach the employment target of $70 \%$ of the population aged 20-64, set for 2020, as provided by the National Employment Strategy for 2014 -2020.

There has now been a favorable economic development (Figure 2), leading to a "consolidation of the labor market, with a significant improvement in the main indicators of employment and unemployment" (Romanian Government, 2021b). 


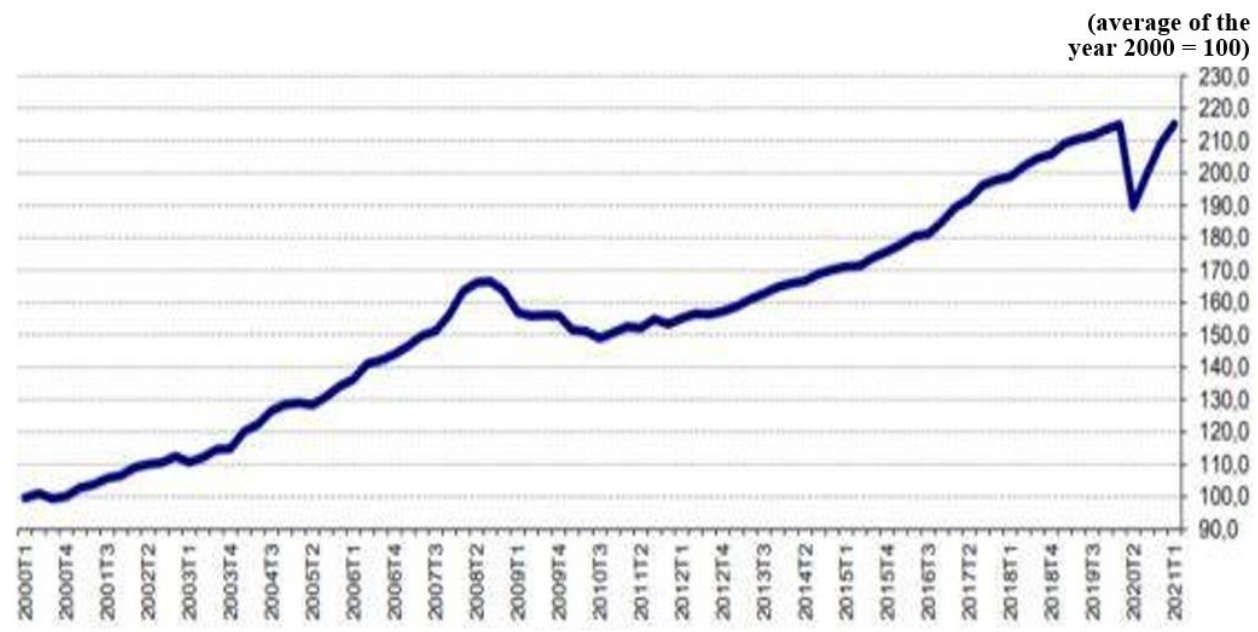

Figure no.2 Romania's quarterly gross domestic product (2000-2021, seasonally adjusted data)

Sursa: Bursa.ro (2021)

At that time (2014), Romania aimed for 2020 to reach the $70 \%$ employment target set for the population aged 20-64. In the end, this assumed objective was exceeded, reaching 73\%, the increase being systematic: “(...) In the period 2015-2019, Romania gained 4.9 percentage points in the employment rate of the working population aged $20-64$ (...). In 2015 , the employment rate of the population aged $20-64$ was $66.0 \%$, increasing by 0.3 percentage points compared to the previous year. The employment rate for the 20-64 age group continued, in 2016, the upward trend started in 2013 amid accelerated economic growth reaching the level of $66.3 \%$. The upward trend manifested by the employment rate of the working age population of 20-64 years was maintained in the following years, reaching values of $68.8 \%$ in 2017 , respectively $69.9 \%$ in 2018 . In 2019 , the employment rate (for the 20-64 age group) reached $70.9 \%$, up 1 percentage point compared to 2018, in the context of a European average of $73 \%$ of the EU-27 employment rate" (Romanian Government, 2021b).

At the same time, unemployment experienced an appreciable improvement, the situation of the unemployment rate by counties, at the end of 2020, being presented below (Figure 3). 


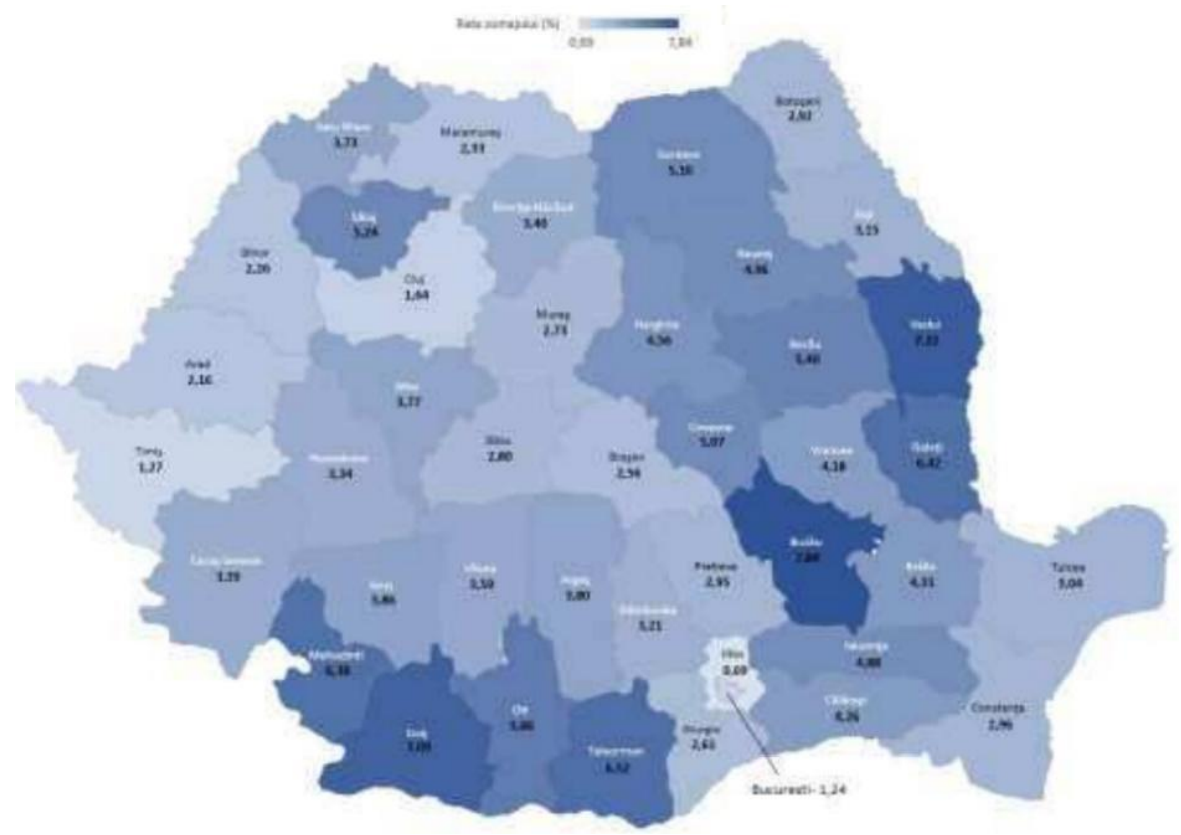

Figure 3. Unemployment rate on 31 December 2020

Source:ANOFM (2021)

Prior to the pandemic crisis, the employment rate by region, sex and level of education (population 20-64 years) is further illustrated (Figure 4). 100,0

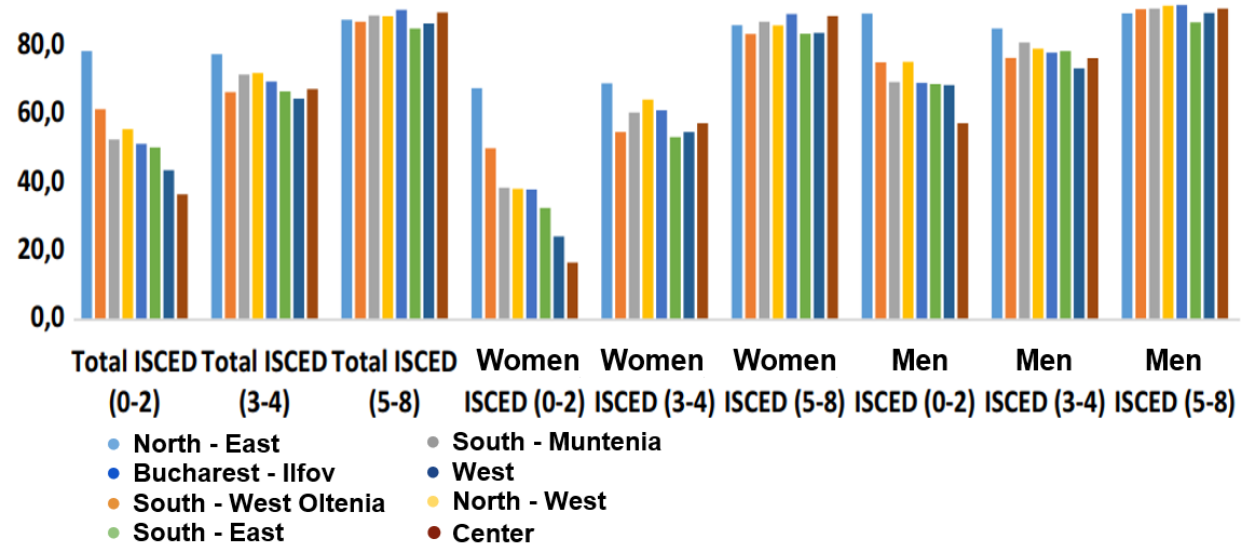

Figure 4. Employment rate by region, sex and level of education (population aged 20-64) in 2019

Source: Romanian Government (2021a) 
The employed population in Romania, a total of 8.408 million people (2019) represents approximately $4.3 \%$ of the employed population in the European Union (EU-27), where there are approximately 195 million people. Below is the situation of the employed population (aged 15-64) by region and sex (Table 3).

Table 3 Employed population in 2019 (aged 15-64) by region and sex (thousands of people)

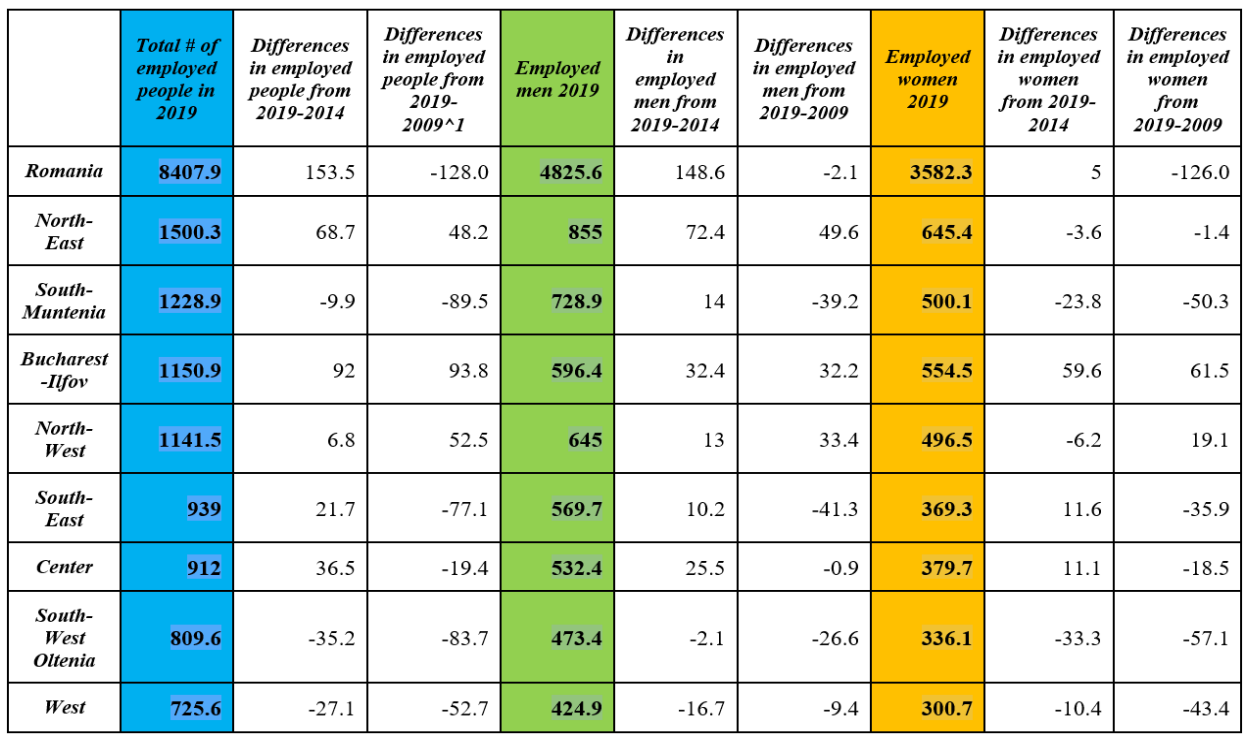

Source: Romanian Government (2021)

Regarding the distribution of the employed population by economic activities, according to the previously mentioned source, the significant sectors are agriculture, forestry and fishing $(21.1 \%$ of the total employed population), manufacturing industry $(18.9 \%)$, wholesale and retail trade $(14.6 \%)$, constructions $(8.2 \%)$ and transport and storage $(5.9 \%)$ ".

The further capitalization of the national economic potential means maintaining a high level of employment. The current strategic guidelines in this regard take into account (overall target: increasing quality employment, in terms of sustainability, so that, by the end of 2027 , the employment rate of the population aged 20-64 will have been 75\%), beyond migration and external mobility, factors related to unfavorable demographic evolution, regional / urban-rural disparities - in terms of investment level, productivity, competitiveness, imbalance between labor supply and demand.

In fact, the new vision presupposes that in the perspective of 2027 "the Romanian labor market will become dynamic, sustainable, resilient, and 
proactive, based on social innovation. The workforce will be sustainably employed and equipped with the skills needed to cope with technological, digital and global trends. This will ensure sustainable competitiveness and flexible, adapted and adequate social protection systems." (Romanian Government, 2021a). The specific objectives of the National Strategy for Employment in Romania within 2021-2027, recently set by the Romanian Government, are:

"(i) sustainable integration of the available labor force on the labor market;

(ii) increasing the economic potential of young people; (

iii) modernizing and strengthening labor market institutions in order to create an environment conducive to the support of a flexible, functional and resilient labor market;

(iv) strengthening the vocational training system for adults to better connect to the requirements of the labor market." (Romanian Government, 2021a).

The results to be obtained by implementing the National Strategy for Employment in Romania within 2021-2027 refer mainly to reducing the labor shortage, improving access to employment for disadvantaged groups, streamlining measures to activate the social categories disadvantaged on the labor market, debureaucratization, efficiency and flexibility of the activity of the public employment service or strengthening the role of the social economy in terms of employment of disadvantaged people, etc. They present an appreciable degree of feasibility, taking into account the achievements of the period 2014 - 2020, estimating that the existing good practices, once capitalized and multiplied, are likely to determine the sustainable increase of a quality employment.

\section{Conclusions}

Both at EU and Member State level, it is very important to increase the number of jobs, but also the quality of their conditions, in the context of the free movement of people.

The efficiency of the employment policies takes place in perpetuity, currently being elaborated in several strategic orientations of Romania in this respect. We have taken into account in this paper the fact that the national labor market is characterized by a series of difficulties, risks and weaknesses, encountered to a lesser extent in other states of the European Union, then presenting the reaction measures of the Romanian Government and the guidelines adopted, including possible outcomes. 
Increasing the quality of employment means emphasizing the promotion of highly skilled, skilled labor (including in relation to IT-based work), but also adaptable, in unforeseen contexts.

\section{References}

Anghelache, C., Manole, A., Anghel, M. G., \& Sacală, C. (2016). The Analysis of the Labor Force Resources Market. Romanian Statistical Review, Supplement 12, 93-100.

https://insse.ro/cms/sites/default/files/field/publicatii/revista romana de statistica supliment nr12 2016 0.pdf

ANOFM. (2021). Raport de activitate pe anul 2020 [Activity report for 2020]. https://www.anofm.ro.

Bostan, I., \& Grosu, V. (2010). The social effects of the current economic crisis on the European Union labour market. Revista de Cercetare si Interventie Sociala, 31, 7-21.

https://www.researchgate.net/publication/49611363 The social effects of the current economic crisis on the European_Union labour marke $\underline{\mathrm{t}}$

Burciu, A. (coord.). (2008). Introducere in management [Introduction to management]. Editura Economică.

Bursa.ro. (2021, May 19). PIB-ul României a recuperat, în mare parte, contracția suferită în lockdown-ul Covid-19 [Romania's GDP largely recovered from the contraction suffered in the Covid-19 lockdown]. https://www.bursa.ro/pib-ul-romaniei-a-recuperat-in-mare-partecontractia-suferita-in-lockdown-ul-covid-19-69642348

European Commission. (2010). A strategy for smart, sustainable and inclusive growth. https://eur-

lex.europa.eu/LexUriServ/LexUriServ.do?uri=COM:2010:2020:FIN:EN:P $\underline{\mathrm{DF}}$

European Commission. (2019). Joint Report on Employment of the European Commission and the Council / Project accompanying the Communication from the Commission on the Annual Sustainable Growth Strategy. https://eur-lex.europa.eu/legalcontent/en/ALL/?uri=CELEX:52019DC0653

European Economic and Social Committee (2020). Employment in EU. https://www.eesc.europa.eu/ro/policies/policy-areas/employment

European Parliament. (2021). Employment policy. https://www.europarl.europa.eu/ftu/pdf/en/FTU 2.3.3.pdf 
European Union. (2020). Council Decision (EU) 2020/1512 of 13 October 2020 on guidelines for the employment policies of the Member States. Official Journal of the European Union, 22-28. https://eur-lex.europa.eu/legalcontent/EN/TXT/PDF/?uri=CELEX:32020D1512\&from=RO

Morariu, A. (2014). The Management of the HumanResources in the Public Health System: The Complexity And The Euro-Global Socio-Economic Challenges. Revista de cercetare si interventie sociala, 44, 266-278. https://www.rcis.ro/images/documente/rcis44 16.pdf

Romanian Government. (2021a). Strategia Națională pentru Ocuparea Forței de Muncă 2021-2027 [National Employment Strategy 2021-2027]. https://mmuncii.ro/i33/images/Documente/MMPS/SNOFM 20212027.pdf

Romanian Government. (2021b). Notă de fundamentare aferentă Hotărârii Guvernului privind aprobarea Strategiei Naționale pentru Ocuparea Forțtei de Muncă 2021-2027 şi a Planului de acţiuni pe perioada 2021 - 2027 pentru implementarea Strategiei Nationale pentru Ocuparea Forţei de Muncă 2021-2027 [Note related to the Government Decision on the approval of the National Employment Strategy 2021-2027 and the Action Plan for the period 2021 - 2027 for the implementation of the National Employment Strategy 2021-2027]. https://sgg.gov.ro/1/wp-content/uploads/2021/05/NF-19.pdf 